BIODIK: Jurnal IImiah Pendidikan Biologi
ISSN 2580-0922 (online), ISSN 2460-2612 (print)
Volume 6, Nomor 02, Tahun 2020, Hal. 187-199
Available online at:
https://online-journal.unja.ac.id/biodik

Research Article OPEN ACCESS

\title{
Analisis dan Rekonstruksi Komponen Penyusun Lembar Kerja Peserta Didik Struktur dan Fungsi Jaringan Tumbuhan
}

\author{
(Analysis and Reconstruction of the Student Worksheet Components \\ on Structure and Function of Plant Tissue Subject)
}

\author{
Nadia*, Bambang Supriatno, Sri Anggraeni \\ Program Studi Pendidikan Biologi Universitas Pendidikan Indonesia \\ J. Dr. Setiabudi No. 229, Bandung 40154, Indonesia \\ *Corresponding Author: nadiaafikaa@gmail.com
}

\begin{tabular}{|c|c|}
\hline Informasi Artikel & ABSTRACT \\
\hline $\begin{array}{l}\text { Submit: } 21-05-2020 \\
\text { Diterima: } 27-06-2020 \\
\text { Dipublikasikan: } 28-06-2020\end{array}$ & $\begin{array}{l}\text { Student worksheets are guidelines used by teachers and students in } \\
\text { practicum activities. This study aims to analyze and reconstruct the } \\
\text { students worksheets categorized as less qualified and irrelevant } \\
\text { according to the standards. This research is a descriptive qualitative } \\
\text { analysis research which aims to analyze and reconstruct student } \\
\text { worksheets with three stages: 1)Analysis; 2)Trial ; 3)Reconstruction. } \\
\text { The analysis was conducted on } 6 \text { student worksheets on Structure } \\
\text { and Function of Plant Tissue Subject based on KTSP Curriculum and } \\
2013 \text { Curriculum using the Laboratory Activity Analysis Form } \\
\text { instrument and the Vee Diagram scoring table. The trial was } \\
\text { conducted at the FPMIPA Plant Structure Laboratory, Universitas } \\
\text { Pendidikan Indonesia. Student worksheets reconstruction was based } \\
\text { on the problems found in the conceptual, practical and knowledge } \\
\text { construction aspects subsequent to analysis and testing conducted. } \\
\text { The results showed that there were problems with the student } \\
\text { worksheets in the conceptual, practical and knowledge construction } \\
\text { aspects. In the conceptual aspect, for the suitability of competence } \\
\text { with Basic Competence and suitability of activities with the cognitive } \\
\text { level of students only reached the percentage of 16.6\%. In the } \\
\text { practical aspect, 66.7\% of the student worksheets were found to be } \\
\text { irrelevant in terms of procedures. In the aspect of knowledge } \\
\text { construction, 66.6\% of the questions used in the student worksheets } \\
\text { were found to be irrelevant with the practicum activities. Based on the } \\
\text { scores obtained from Diagram Vee, the student worksheet does not } \\
\text { reach an ideal score (18). Knowledge Claim component of Vee } \\
\text { Diagram was absent (0). } \\
\text { Keywords: Practicum Activities, Student Worksheets, Structure and } \\
\text { Function Of Plant Tissue }\end{array}$ \\
\hline Penerbit & ABSTRAK \\
\hline $\begin{array}{l}\text { Program Studi Pendidikan } \\
\text { Biologi, Fakultas Keguruan dan } \\
\text { Ilmu Pendidikan, Universitas } \\
\text { Jambi }\end{array}$ & $\begin{array}{l}\text { Lembar kerja peserta didik merupakan pedoman yang digunakan oleh } \\
\text { guru dan siswa dalam kegiatan praktikum. Penelitian ini bertujuan } \\
\text { untuk menganalisis dan merekonstruksi lembar kerja peserta didik } \\
\text { yang kurang berkualitas dan tidak sesuai dengan standar yang telah } \\
\text { ditetapkan. Penelitian ini merupakan penelitian analisis deskriptif } \\
\text { kualitatif yang bertujuan untuk menganalisis dan merekonstruksi } \\
\text { lembar kerja peserta didik dengan tahapan 1) Analisis; 2) Coba; 3) } \\
\text { Rekonstruksi. Analisis dilakukan pada } 6 \text { LKPD Struktur dan Fungsi }\end{array}$ \\
\hline
\end{tabular}


Jaringan Tumbuhan berdasarkan Kurikulum KTSP dan Kurikulum 2013 menggunakan instrumen Form Analisis Kegiatan Laboratorium dan tabel penskoran Diagram Vee. Uji coba dilakukan di Laboratorium Struktur Tumbuhan FPMIPA Universitas Pendidikan Indonesia. Rekonstruksi LKPD dilakukan berdasarkan permasalahan yang ditemukan pada aspek konseptual, praktikal dan konstruksi pengetahuan setelah melakukan analisis dan ujicoba. Hasil penelitian menunjukkan bahwa terdapat permasalahan pada LKPD Struktur dan Fungsi Jaringan Tumbuhan dari aspek konseptual, praktikal dan konstruksi pengetahuan. Pada aspek konseptual, untuk kesesuaian kompetensi dengan Kompetensi Dasar dan kesesuaian kegiatan dengan tingkat kognitif siswa, persentasenya hanya $16,6 \%$. Pada aspek praktikal $66,7 \%$ dari LKPD yang dianalisis prosedurnya tidak tepat sehingga objek fenomena yang muncul tidak relevan dengan tujuan/judul LKPD. Pada aspek konstruksi pengetahuan 66,6\% dari LKPD yang dianalisis pertanyaannya dapat dijawab tanpa melakukan praktikum dan tidak ada pertanyaan mengenai interpretasi data, kemunculan suatu prinsip dan analisis sehingga penarikan kesimpulan tidak berdasarkan fakta dan tidak menggambarkan judul/tujuan. Berdasarkan perolehan skor komponen Diagram Vee LKPD Struktur dan Fungsi Jaringan Tumbuhan belum mencapai skor ideal (18). Komponen Diagram Vee yang tidak muncul sama sekali adalah klaim pengetahuan (skor 0 ).

Katakunci: Kegiatan Praktikum, Lembar Kerja Peserta Didik,Struktur dan Fungsi Jaringan Tumbuhan

This BIODIK : Jurnal IImiah Pendidikan Biologi is licensed under a CC BY-NC-SA (Creative Commons Attribution-ShareAlike 4.0 International License)

\section{PENDAHULUAN}

Kegiatan praktek adalah komponen penting dalam pendidikan sains, baik untuk tujuan mengembangkan pengetahuan ilmiah siswa maupun mengembangkan pengetahuan siswa tentang sains (Millar, 2004). Tujuan utama dari kegiatan praktek adalah (1) membantu siswa mengembangkan pengetahuan mereka tentang alam dan pemahaman mereka tentang beberapa ide-ide utama, teori dan model yang digunakan untuk menjelaskan sains; (2) membantu siswa belajar bagaimana menggunakan beberapa peralatan ilmiah dan mempelajari beberapa prosedur ilmiah; (3) mengembangkan pemahaman siswa tentang pendekatan ilmiah terhadap inkuiri (misalnya tentang bagaimana merancang suatu investigasi, menilai dan mengevaluasi data, memproses data untuk menarik kesimpulan, mengevaluasi hasil uji coba) (Millar, R \& Abrahams, 2009).

Kegiatan praktek adalah faktor kunci yang menyemangati, menginspirasi dan menarik minat siswa dalam mempelajari sains. Kegiatan praktek memberikan siswa pemahaman tentang bagaimana pengetahuan Biologi dihasilkan melalui percobaan dan observasi (The Society for Biology, 2010; Wibowo, Y. G., \& Sadikin, A, 2019). Kegiatan praktek juga membantu siswa untuk memahami konsep sains dengan lebih baik lagi. Pengaplikasian kegiatan praktek sebagai suatu strategi dalam pembelajaran akan memberikan kesempatan kepada siswa untuk mempelajari konten dengan mengeksplorasi dan terlibat dalam kegiatan praktis secara langsung (Festile, 2017). Dasar dari kegiatan praktek yang baik adalah kegiatan yang terencana, memiliki tujuan, dipimpin oleh guru yang ahli dibidangnya, sering 
melakukan praktek dengan metode yang bervariasi, fasilitas laboratorium yang memadai, dukungan teknis, percobaan secara langsung, investigasi, mempertimbangkan resiko dan hasilnya sesuai dengan tujuan (Holman 2017; Hakim, N., 2015).

Belajar sains dengan praktek bukan hanya belajar tentang konten melainkan juga merupakan suatu proses pemberian pengalaman belajar sehingga membangun ketrampilan (skill) untuk memperoleh pengetahuan (how to know). Kegiatan belajar sains tersebut dapat membangun kemampuan berfikir kritis, mengembangkan kreativitas dan inovasi, membangun kerjasama dan melatih keterampilan berkomunikasi. Dengan demikian bila pembelajaran sains dikemas dengan metode dan strategi yang tepat maka akan mampu mengkonstruksi ketrampilan yang dibutuhkan untuk hidup dan bekerja dikehidupan abad 21. Kegiatan praktek dapat diarahkan untuk mengembangkan berbagai kompetensi sebagai outcome pembelajaran (Supriatno, 2018). Kegiatan guru (teacher activity), kegiatan siswa (student activity) dan Hasil pemmbelajaran (Learning outcome) memiliki keterkaitan (Sadikin, A., \& Hakim, N, 2019). Adanya penerapan praktikum sangat penting dalam pembelajaran Biologi, karena kegiatan praktikum sangat erat hubungannya dengan keterampilan proses sains. Melalui praktikum, pendidik dapat mengembangkan sikap ilmiah yang mendukung proses perolehan pengetahuan (produk keilmuan) dalam diri peserta didik. Penanaman sikap merupakan tujuan utama pendidikan dan pembelajaran (Sadikin, A, 2015; Sadikin, A, 2018). Pelaksanaan praktikum dapat memunculkan keterampilan proses sains seperti keterampilan mengamati, berhipotesis, memprediksi, melakukan percobaan, interpretasi, berkomunikasi dan menyimpulkan (Putri, Yolida, \& Sikumbang, 2019; Safahi, L., Pusporini, A., Susilo, S., \& Akbar, B., 2020). Dalam kegiatan praktikum biasanya guru menyediakan pedoman berupa Lembar kerja peserta didik (LKPD). Keberadaan Lembar kerja peserta didik dapat memengaruhi keberhasilan pembelajaran di laboratorium karena sebagai acuan atau pedoman siswa dalam melakukan kegiatan praktikum (Bago, 2018).

Berdasarkan analisis terhadap 6 LKPD Struktur dan Fungsi Jaringan Tumbuhan ditemukan 1) ketidakselarasan antara tujuan yang ingin dicapai dengan kegiatan yang dilaksanakan, 2) Langkah kerja yang digunakan tidak tepat, 3) Konstruksi pengetahuan tidak berdasarkan fakta, 4) LKPD yang digunakan tidak representatif. Penelitian lainnya menyebutkan bahwa penuntun praktikum Struktur dan Fungsi Jaringan Tumbuhan saat ini masih besifat verifikasi dengan panduan model resep (cookbook) dan kegiatan praktikum lebih menekankan pada hasil (produk) dan bukan pada proses, sehingga sedikit sekali kesempatan yang diberikan pada siswa untuk mengalami sendiri usaha ilmiah dalam memecahkan masalah-masalah baru (Bago, 2018). Temuan ini sejalan dengan hasil studi lapangan Supriatno, 2009; Wahidah, Supriatno, \& Kusumastuti, (2018) yang menyatakan hanya 24\% Desain Kegiatan Laboratorium (DKL) yang dapat dikerjakan dengan hasil sesuai prosedur dan tuntas dari segi analisis data dan penarikan kesimpulan, sehingga tidak menunjang konstruksi pengetahuan. Untuk itu perlu dilakukan analisis dan rekonstruksi terhadap LKPD Struktur dan Fungsi Jaringan Tumbuhan agar menjadi LKPD yang berkualitas dan dapat menunjang konstruksi pengetahuan. Konstruksi pengetahuan adalah 
pusat dari proses pembelajaran yang menentukan keberhasilan pembelajaran dengan segala upaya. Dalam pendekatan kognitif dan konstruktivisme pembelajaran, konstruksi pengetahuan memainkan peran penting dalam menentukan efektivitas belajar dengan memfokuskan tentang bagaimana manusia memproses informasi dan mengubahnya menjadi pengetahuan (Woolfolk, 2008; Hashim, Mohaffyza Mohamad, \& Nadrah Wan Muda, 2018; Zulfaidhah, Z., Palenewen, E., \& Hardoko, A., 2018).

\section{METODE PENELITIAN}

Penelitian ini merupakan penelitian analisis deskriptif kualitatif yang bertujuan untuk menganalisis dan merekonstruksi lembar kerja peserta didik dengan tahapan 1) Analisis; 2) Coba; 3) Rekonstruksi.

\section{Analisis}

Analisis dilakukan pada 6 sampel LKPD Struktur dan Fungsi Jaringan Tumbuhan dengan kurikulum yang berbeda. 2 diantaranya berdasarkan kurikulum KTSP sedangkan 4 LKPD lainnya berdasarkan kurikulum 2013. Tahapan analisis dilakukan untuk mengetahui apakah LKPD Struktur dan Fungsi Jaringan Tumbuhan yang digunakan sudah memenuhi kriteria LKPD yang dapat mengkonstruksi pengetahuan. Instrumen yang digunakan adalah Form Analisis Kegiatan Laboratorium dan tabel penskoran Diagram Vee yang diadaptasi dari Novak dan Gowin (1984).

\section{Coba}

Uji coba dilakukan di Laboratorium Struktur Tumbuhan FPMIPA Universitas Pendidikan Indonesia dengan menggunakan langkah kerja pada salah satu LKPD yang belum dimodifikasi. Langkah kerjanya dimulai dengan membersihkan mikroskop dengan tisu yang sudah dibasahi dengan alkohol,selanjutnya sediaan awetan penampang melintang akar diletakkan di atas meja objek mikroskop untuk diamati. Objek yang telah diamati digambarkan pada tabel pengamatan yang telah disediakan.

\section{Rekonstruksi}

Rekonstruksi LKPD dilakukan dengan memperbaiki permasalahan yang ditemukan pada aspek konseptual, praktikal dan konstruksi pengetahuan. Dari aspek konseptual LKPD direkonstruksi dengan menyesuaikan konten dan kompetensi dengan Kompetensi Dasar yang telah ditetapkan kurikulum, dari aspek praktikal dikembangkan langkah kerja yang lebih tepat dan terstruktur sehingga mudah dieksekusi, dari aspek konstruksi pengetahuan pertanyaan yang ada pada LKPD dikaitkan dengan fakta yang ditemukan untuk menggiring penemuan konsep, prinsip dan teori melalui proses interpretasi data. 


\section{Hasil Analisis LKPD}

Hasil analisis menggunakan Form Analisis Kegiatan Laboratorium menunjukkan permasalahan pada LKPD Struktur dan Fungsi Jaringan Tumbuhan dari aspek konseptual, praktikal dan konstruksi pengetahuan.

Tabel 1. Analisis aspek konseptual pada LKPD Struktur dan Fungsi Jaringan Tumbuhan

\begin{tabular}{cccc}
\hline \multirow{2}{*}{ Parameter Analisis Konseptual } & \multicolumn{2}{c}{$\begin{array}{c}\text { Jumlah LKPD yang Sesuai } \\
\text { Parameter }\end{array}$} & \multirow{2}{*}{ Persentase } \\
\cline { 2 - 3 } & KTSP & K.2013 & \\
\hline Kesesuaian konten dengan KD & - & 3 & $50 \%$ \\
\hline Kesesuaian kompetensi dengan KD & - & 1 & $16,6 \%$ \\
\hline Kesesuaian judul dengan kegiatan & 1 & 2 & $50 \%$ \\
\hline Kesesuaian tujuan dengan langkah kerja & - & 2 & $33,3 \%$ \\
\hline Kesesuaian kegiatan dengan tingkat kognitif siswa & - & 1 & $16,6 \%$ \\
\hline
\end{tabular}

Berdasarkan tabel 1 LKPD Struktur dan Fungsi Jaringan Tumbuhan yang dianalisis bermasalah pada aspek konseptual karena hanya 50\% dari 6 LKPD yang dianalisis yang memiliki kesesuaian antara konten dan judul dengan Kompetensi Dasar. Untuk kesesuaian kompetensi dengan Kompetensi Dasar dan kesesuaian kegiatan dengan tingkat kognitif siswa, persentasenya hanya 16,6\%. Untuk kesesuaian tujuan dengan langkah kerja persentasenya hanya $33,3 \%$. Karena tidak adanya kecocokan kompetensi dasar dengan tujuan dan kegiatan yang disusun maka kompetensi dan tingkat kognitif yang terbentuk juga tidak sesuai. Menurut Dahar (2011; Laelasari \& Supriatno, 2018) pengetahuan yang dapat diperoleh siswa melalui suatu pembelajaran/praktikum bergantung pada dua aspek yang saling berkaitan satu sama lain, yaitu siswa harus mengetahui tujuan dari kegiatan yang akan dilakukan, dan sampai seberapa jauh tujuan tersebut dapat dicapai oleh siswa.

Tabel 2. Analisis aspek praktikal pada LKPD Struktur dan Fungsi Jaringan Tumbuhan

\begin{tabular}{cccc}
\hline \multirow{2}{*}{ Parameter Analisis Praktikal } & \multicolumn{2}{c}{$\begin{array}{c}\text { Jumlah LKPD yang } \\
\end{array}$} & \multicolumn{2}{c}{ Sesuai Parameter } & \multirow{2}{*}{ Persentase } \\
\cline { 2 - 4 } & KTSP & K.2013 & \\
\hline Alat-alatnya sesuai dengan standar/tersedia sekolah & 2 & 4 & $100 \%$ \\
\hline Bahan praktikum dapat disediakan dengan mudah & 2 & 3 & $83,3 \%$ \\
\hline Langkah-langkahnya terstruktur & 2 & 3 & $83,3 \%$ \\
\hline Setiap langkah kerja dapat dieksekusi tanpa kesulitan & - & 2 & $33,3 \%$ \\
\hline Objek/fenomenanya muncul & - & 2 & $33,3 \%$ \\
\hline Ada perekaman data & 2 & 4 & $100 \%$ \\
\hline Objek fenomena relevan dengan judul/tujuan & - & 2 & $33,3 \%$ \\
\hline Memiliki petunjuk safety lab & - & 1 & $16,6 \%$ \\
\hline Prosedurnya tepat & - & 2 & $33,3 \%$ \\
\hline
\end{tabular}

Berdasarkan tabel 2, alat-alat yang digunakan dalam praktikum semuanya sudah sesuai dengan standar di sekolah karena persentasenya sudah $100 \%$. Untuk kemudahan dalam penyediaan bahan praktikum dan langkah kerja yang terstruktur sudah cukup baik karena persentasenya sudah mencapai $83,3 \%$. Untuk langkah kerja yang mudah dieksekusi dan kemunculan objek fenomena persentasenya hanya $33,3 \%$, artinya $66,7 \%$ langkah kerjanya sulit dieksekusi dan objek fenomenanya tidak muncul. Untuk kegiatan perekaman data sudah mencapai 100\% yang berarti pada semua LKPD ada kegiatan perekaman data. Untuk petunjuk safety lab hanya 16,6\% 
LKPD yang memiliki petunjuk safety lab. Untuk objek fenomena yang relevan dengan judul/tujuan serta ketepatan prosedur persentasenya hanya 33,3\%. Artinya 66,7\% dari LKPD yang dianalisis prosedurnya tidak tepat sehingga objek fenomena yang muncul dan tidak relevan dengan tujuan/judul LKPD. Permasalahan pada aspek praktikal terjadi karena sebagian besar LKPD hanya mengadopsi langkah kerja dari LKPD yang sudah ada sebelumnya tanpa melakukan uji coba terlebih dahulu sehingga langkah kerjanya banyak yang tidak tepat dan membingungkan siswa. Temuan ini sesuai dengan penelitian Supriatno, (2013; Wahidah, Supriatno \& Kusumastuti, 2018) yang menyatakan bahwa prosedur praktikum meskipun rinci, beberapa di antaranya tidak terstruktur dan perintahnya membingungkan sehingga menimbulkan penafsiran ganda. Selain itu, gambar ilustrasi yang ditampilkan tidak menggambarkan keadaan aslinya, serta terdapat kalimat yang menunjukkan kesalahan prosedur. Jika terjadi kesalahan prosedur, maka tujuan praktikum tidak dapat tercapai.

Tabel 3. Analisis aspek konstruksi pengetahuan pada LKPD

\begin{tabular}{cccc}
\hline \multirow{2}{*}{ Parameter Analisis Konstruksi Pengetahuan } & \multicolumn{2}{c}{$\begin{array}{c}\text { Jumlah LKPD yang } \\
\text { Sesuai Parameter }\end{array}$} & \multirow{2}{*}{ Persentase } \\
\cline { 2 - 3 } & KTSP & K.2013 & \\
\hline Semua pertanyaan dapat dijawab tanpa praktikum & 1 & 3 & $66,6 \%$ \\
Menanyakan karakter fakta yang muncul & 1 & 3 & $66,6 \%$ \\
Fakta digunakan untuk mengkonstruksi konsep & - & 1 & $16,6 \%$ \\
Ada proses interpretasi data & - & - & $0 \%$ \\
Ada pertanyan terkait kemunculan suatu prinsip & - & - & $0 \%$ \\
Ada pertanyaan terkait analisis & - & - & $0 \%$ \\
Penarikan kesimpulan berdasarkan data yang direkam & - & - & $0 \%$ \\
Kesimpulan yang dibangun menggambarkan & - & - & $0 \%$ \\
judul/tujuan & - & -
\end{tabular}

Berdasarkan tabel 3 pada aspek konstruksi pengetahuan, persentase pertanyaan yang dapat dijawab tanpa praktikum mencapai $66,6 \%$, artinya hanya $33,4 \%$ LKPD yang pertanyaannya bisa dijawab dengan melakukan praktikum. Pertanyaan mengenai fakta yang muncul persentasenya 66,6\%. Fakta yang digunakan untuk mengkonstruksi konsep persentasenya hanya $16,6 \%$. Sedangkan untuk pertanyaan mengenai interpretasi data, kemunculan suatu prinsip dan analisis persentasenya $0 \%$ sehingga penarikan kesimpulan tidak berdasarkan fakta dan tidak menggambarkan judul/tujuan. Temuan ini selaras dengan hasil penelitian Maemunah \& Pramesti (2019) yang menyatakan bahwa pada bagian evaluasi soal-soal yang diberikan pada LKPD idealnya dapat dijawab berdasarkan teks yang disajikan.

Hasil analisis konstruksi pengetahuan menandakan bahwa LKPD Struktur dan Fungsi Jaringan Tumbuhan secara keseluruhan bermasalah pada aspek konstruksi pengetahuan. Permasalahan pada konstruksi pengetahuan juga dibuktikan dari rendahnya perolehan skor komponen diagram Vee (tabel 4) dari 6 LKPD Struktur dan Fungsi Jaringan Tumbuhan yang dianalisis. 


\begin{tabular}{ccccccc}
\hline \multirow{2}{*}{ Komponen Diagram Vee } & \multicolumn{7}{c}{ Perolehan Skor } \\
\cline { 2 - 7 } & \multicolumn{6}{c}{ KTSP } \\
\cline { 2 - 7 } & LKPD 1 & LKPD 2 & LKPD 3 & LKPD 4 & LKPD 5 & LKPD 6 \\
\hline Pertanyaan fokus & 1 & 0 & 0 & 1 & 0 & 3 \\
Objek/Event & 1 & 1 & 1 & 1 & 1 & 2 \\
Teori, prinsip, konsep & 0 & 0 & 0 & 0 & 0 & 1 \\
Catatan/Transformasi & 3 & 1 & 1 & 1 & 1 & 4 \\
Klaim pengetahuan & 0 & 0 & 0 & 0 & 0 & 0 \\
\hline Jumlah Skor & $\mathbf{4}$ & $\mathbf{2}$ & $\mathbf{2}$ & $\mathbf{3}$ & $\mathbf{2}$ & $\mathbf{1 0}$ \\
\hline
\end{tabular}

Berdasarkan tabel 4, pada komponen pertanyaan fokus 3 LKPD menunjukkan skor 0 dan 2 LKPD menunjukkan skor 1 yang artinya tidak ada fokus pertanyaan yang teridentifikasi, sedangkan untuk LKPD yang menunjukkan skor 3 berarti sudah memiliki pertanyaan fokus yang jelas dan dapat diidentifikasi. Pada komponen Objek/Event, 5 LKPD diantaranya menunjukkan skor 1 yang berarti event utama dengan objek yang menyertai dapat diidentifikasi, tapi tidak konsisten dengan pertanyaan fokus. Untuk LKPD dengan skor 2 berarti event utama dengan objek yang menyertai dapat diidentifikasi, dan konsisten dengan pertanyaan fokus. Pada komponen teori, prinsip, konsep 5 LKPD diantaranya menunjukkan skor 0 yang berarti tidak ada konsep yang dapat diidentifikasi. Sedangkan pada LKPD 6 menunjukkan skor 1 yang berarti terdapat konsep tetapi tidak ada prinsip dan teori.

Pada komponen Catatan/Transformasi 5 LKPD diantaranya menunjukkan skor 3 yang berarti berarti ada pencatatan yang teridentifikasi untuk fenomena utama tetapi tidak konsisten dengan pertanyaan fokus. Sedangkan skor 1 berarti pencacatan teridentifikasi tetapi tidak relevan dengan pertanyaan fokus dan fenomena utama. Untuk LKPD 6 sudah menunjukkan skor 4 yang berarti pencatatan teridentifikasi untuk fenomena utama, transformasi data relevan dengan fenomena utama, tingkatan kelas dan kompetensi siswa. Untuk klaim pengetahuan, perolehan skor pada 6 LKPD yang dianalisis seluruhnya menunjukkan skor 0 yang berarti tidak ada klaim pengetahuan yang teridentifikasi. Hal ini terjadi karena pertanyaan yang ada pada kegiatan praktikum hanya sampai menanyakan karakter objek yang muncul dan tidak ada pertanyaan yang menggiring penemuan konsep, prinsip dan teori untuk klaim pengetahuan. Perolehan skor komponen Diagram Vee dari 6 LKPD Struktur dan Fungsi Tumbuhan belum mencapai skor ideal (18).

Berdasarkan hasil analisis secara konseptual, praktikal dan konstruksi pengetahuan menunjukkan bahwa LKPD Struktur dan Fungsi Jaringan Tumbuhan yang digunakan pada Kurikulum KTSP maupun Kurikulum 2013 tidak representatif, karena kegiatan yang disusun disetiap LKPD umumnya sama meskipun tuntutan kurikulumnya sudah berbeda. Selain itu permasalahan yang ditemukan pada setiap LKPD umumnya juga sama yaitu masalah dari aspek konseptual, praktikal dan konstruksi pengetahuan. Hasil penelitian Supriatno, 2009; Rima, Munandar, \& Anggraeni, 2020) terhadap 46 sampel Lembar kerja peserta didik (LKPD) Biologi diketahui bahwa 24\% LKPD dapat dikerjakan dengan hasil sesuai prosedur, dan tuntas dari segi analisis dan penarikan kesimpulan, sisanya $76 \%$, bermasalah dalam hal: 1) langkah kerja tidak terstruktur, 2) prosedur sulit dikerjakan, 3) tabel data kaku dan hasil menimbulkan miskonsepsi, 4) tidak tuntas, dan 5) memerlukan waktu lama. Hasil analisis juga menunjukkan bahwa LKPD Struktur dan Fungsi Jaringan 
Tumbuhan yang ada saat ini masih mempunyai kualitas yang rendah. Rendahnya kualitas Lembar Kerja Peserta Didik (LKPD) disebabkan karena LKPD yang digunakan sering tidak memperhatikan kelayakan isi, konstruksi, teknis dan penyajian (Azmi, Prastowo, \& Maslena, 2018).

\section{Hasil Uji Coba}

Uji coba yang dilakukan menggunakan langkah kerja pada salah satu LKPD yang belum direkonstruksi menimbulkan beberapa kendala diantaranya sulitnya memunculkan objek fenomena karena langkah kerja yang digunakan tidak tepat. Selain itu langkah kerja yang diberikan juga tidak terstruktur dan tidak lengkap sehingga sulit untuk dieksekusi. Kesalahan pada langkah kerja akan mempengaruhi hasil yang didapatkan dan menyebabkan kesulitan dalam memunculkan objek fenomena sehingga objek fenomena yang muncul tidak sesuai dengan tujuan praktikum. Hasil penelitian Laelasari \& Supriatno (2018) menunjukkan bahwa 20\% proses kegiatan laboratorium yang dilakukan mengacu pada tujuan, memiliki struktur yang logis dan sistematis, serta dapat menghasilkan data yang diharapkan, sisanya sebanyak $70 \%$ menunjukkan langkah kerja tidak sistematis, tidak logis, dan juga tidak dapat memperoleh data yang tepat.

\section{Hasil Rekonstruksi LKPD}

Rekonstruksi LKPD dilakukan berdasarkan permasalahan yang ditemukan pada aspek konseptual, praktikal dan konstruksi pengetahuan setelah melakukan analisis dan uji coba. Pada aspek konseptual kegiatan praktikum disusun dengan menyesuaikan kegiatan dengan tuntunan kurikulum yang berlaku sehingga kegiatan praktikum yang dilakukan siswa sesuai dengan tingkatan kognitif siswa. Adanya kesesuaian materi dalam penuntun praktikum dengan standar kompetensi maka pendidik akan terarah dalam mencapai kompetensi yang seharusnya dikuasai oleh peserta didik (Agustina, 2016). Pada aspek praktikal langkah kerja disusun dengan tepat agar dapat memunculkan objek fenomena yang relevan melalui aktivitas hands-on. Selain itu langkah kerja praktikum dibuat lebih terstruktur agar mudah dieksekusi dan mendorong terbentuknya keterampilan utama abad 21 yaitu keterampilan 4C (Creativity, Critical Thinking \& Problem Solving, Communication, Collaboration).

Pada aspek konstruksi pengetahuan pertanyaan-pertanyaan yang ada di LKPD disusun dengan dengan berpedoman pada Diagram Vee. Menurut Diagram Vee yang dikemukan oleh Novak dan Gowin (1984) dalam kegiatan praktikum pengetahuan dapat dibentuk melalui beberapa tahapan diantaranya pertanyaan fokus yang relevan dengan objek, peristiwa utama, pencatatan dan penemuan fakta, transformasi, representasi data, interpretasi data, penemuan konsep, prinsip dan teori dan yang terakhir adalah knowledge claims dan value claims. Dalam konstruksi pengetahuan atau interpretasi pengetahuan, semua elemen berfungsi secara interaktif dengan yang lain untuk memahami peristiwa objek yang diamati (Novak \& Gowin, 1984). Pertanyaan yang mengacu pada tujuan berarti pertanyaan tersebut dapat mengarahkan pada pencapaian konsep yang tercantum dalam tujuan, sementara pertanyaan yang mengacu pada proses berarti bahwa pertanyaan

\section{$194 \quad$ Nadia. $\boldsymbol{d k k}$}


tersebut mengarahkan pada langkah kerja dan data yang dihasilkan (Laelasari \& Supriatno, 2018).

Lembar kerja peserta didik disusun bukan hanya untuk memenuhi syarat kurikulum atau syarat suatu pembelajaran Sains, tapi lembar kerja peserta didik harus dapat membantu siswa agar dapat mengkonstruksi pengetahuannya, memberikan kontribusi terhadap pengembangan keterampilan dasar sains siswa, serta mengembangkan kemampuan berpikir siswa sehingga kegiatan praktikum menjadi lebih bermakna. Kebermaknaan praktikum akan terfasilitasi jika LKPD menekankan pada penyajian teori yang koheren dengan pengamatan objek atau kejadian, bersifat kontekstual karena hasil praktikum dihubungkan dengan permasalahan dalam kehidupan sehari-hari siswa, dan mengembankan inkuiri dengan cara penyelidikan dan penemuan terhadap objek atau peristiwa yang diteliti (Hindriana, 2020). Hasil rekonstruksi Lembar kerja peserta didik Struktur dan Fungsi Jaringan Tumbuhan dapat dilihat pada Gambar 1.

\section{LEMBAR KERJA PESERTA DIDIK}

Nama

Kelas

Alokasi waktu

\section{Bagaimanakah Struktur Jaringan Penyusun Organ Tumbuhan?}

\section{A. Tujuan}

Mengamati struktur jaringan penyusun akar, batang, daun dan menentukan fungsi jaringan-jaringan tersebut berdasarkan strukturnya.

\section{B. Landasan Teori}

Jaringan adalah sekelompok sel yg mempunyai struktur, fungsi yang sama dan terikat oleh bahan antar sel serta membentuk suatu kesatuan. Jaringan pada tumbuhan terdiri dari:

1. Jaringan Maristem, yaitu jaringan muda yang sel-selnya selalu aktif membelah.

2. Jaringan Dewasa, yaitu jaringan yang telah mengalami deferensiasi dan tidak membelah lagi. Jaringan ini terdiri dari:

a. Jaringan epidermis, memiliki susunan sel rapat dan tidak ada ruang antarsel. Jaringan ini berfungsi sebagai pelindung pada permukaan semua organ tumbuhan.

b. Jaringan parenkim, berfungsi sebagai penyusun sebagian besar jaringan pada akar, batang, daun, buah, dan biji. Terdiri atas sel-sel yang berukuran besar dan berdinding tipis. Berdasarkan bentuknya jaringan parenkim terdiri dari:

$>$ Parenkim palisade, merupakan parenkim penyusun mesofil pada daun. Jaringan ini terdapat pada biji dengan bentuk sel panjang, tegak, mengandung banyak kloroplas.

$>$ Parenkim bunga karang, merupakan jaringan penyusun mesofil daun yang berukuran tidak tetap dan ruang antar selnya lebar.

3. Jaringan Penyokong, terdiri dari:

a. Jaringan kolenkim, yaitu jaringan penyokong atau penguat pada organ tumbuhan muda dan tanaman herba. Struktur jaringan ini membentuk untaian atau silinder. Terdapat pada batang, daun dan biji.

b. Jaringan sklerenkim, yaitu jaringan penguat yang terdiri dari sel-sel mati. Bentuk selnya membulat dengan dinding sel mengalami penebalan. Terletak pada perisikel, korteks dan diantara xilem dan floem.

4. Jaringan pengangkut, terdiri dari:

a. Xilem, yaitu jaringan pengangkut zat makanan yang menyalurkan air dan mineral dari akar menuju ke daun dan bagian tubuh lainnya. Berbentuk seperti tabung memanjang dan pada dinding selnya terdapat lubang-lubang atau pori-pori. Jaringan ini terdapat pada akar, batang dan daun tumbuhan 
b. Floem, yaitu jaringan pengangkut zat makanan dari hasil fotosintesis dari daun ke seluruh tubuh tumbuhan. Berbentuk tabung dengan ujung yang berlubang dan dindingnya tebal. Jaringan ini terdapat pada akar, batang dan daun tumbuhan.

5. Jaringan gabus, yaitu jaringan yang melindungi jaringan lain agar tidak kehilangan banyak air karena selsel gabus bersifat kedap air.Strukturnya memanjang dan rapat sehingga tidak terdapat ruang antarsel. Sel gabus dapat ditemukan dipermukaan luar batang.

C. Alat dan Bahan

Alat

$>$ Mikroskop

Bahan

$>$ Tisu lensa

$>$ Alkohol 70\%

$>$ Preparat sayatan melintang akar

$>$ Preparat sayatan melintang batang

$>$ Preparat sayatan melintang daun

D. Langkah Kerja

1. Bersihkanlah lensa mikroskop dengan mengusapkan secara perlahan dan hati-hati tisu lensa yang sudah dibasahi dengan alkohol 70\%. Jangan membersihkan lensa dengan tisu atau lap kain biasa.

2. Letakkanlah preparat sayatan melintang akar di meja objek mikroskop.

3. Amatilah preparat yang sudah diletakkan dimeja objek dengan mengatur cahaya dan perbesarannya.

4. Mulailah dengan perbesaran kecil (4x10) terlebih dahulu, kemudian baru menggunakan perbesaran selanjutnya untuk mendapatkan gambar objek yang lebih jelas.

5. Gambarlah objek yang telah kamu amati pada tabel pengamatan yang telah disediakan dan berilah keterangan berupa jaringan yang terdapat pada gambar tersebut.

6. Ulangi langkah nomor 2-5 untuk preparat batang dan daun.

7. Jawablah pertanyaan-pertanyaan pada LKPD ini sesuai dengan hasil pengamatanmu.

\section{Hasil Pengamatan}

\begin{tabular}{|c|c|c|c|}
\hline No. & $\begin{array}{c}\text { Organ yang } \\
\text { diamati }\end{array}$ & $\begin{array}{c}\text { Gambar hasil pengamatan beserta } \\
\text { keterangan }\end{array}$ & $\begin{array}{c}\text { Perbesaran yang } \\
\text { digunakan }\end{array}$ \\
\hline 1 & Akar & & \\
\hline 2 & Batang & & \\
\hline 3 & Daun & & \\
\hline
\end{tabular}

E. Pertanyaan

1. Berdasarkan hasil pengamatanmu, bagaimana bentuk sel pada lapisan terluar?

2. Berdasarkan hasil pengamatanmu, apakah terdapat perbedaan bentuk sel pada lapisan terluar dengan bentuk sel pada lapiran berikutnya?

3. Apa yang dimaksud dengan jaringan?

4. Berdasarkan hasil pengamatanmu, jaringan apa saja yang kamu temukan pada organ akar, batang, daun dan bagaimana susunan sel dari setiap jaringan tersebut.

Setelah menjawab soal ini, berilah keterangan pada gambar hasil pengamatanmu!

5. Berdasarkan hasil pengamatanmu, bagaimana struktur jaringan penyusun organ:
a. Akar
b. Batang
c. Daun

6. Apakah terdapat perbedaan antara jaringan penyusun akar, batang dan daun? Jika ya, apa yang menyebabkan perbedaan tersebut?

7. Apakah bentuk dan struktur jaringan penyusun organ tumbuhan mempengaruhi fungsinya? Jelaskan!

8. Sebutkan fungsi dari masing-masing jaringan yang terdapat pada akar, batang dan daun!

\section{Nadia. $\boldsymbol{d k k}$}


Gambar 1. Hasil rekontruski LKPD Struktur dan Fungsi Jaringan Tumbuhan

\section{KESIMPULAN}

Hasil analisis terhadap 6 LKPD Struktur dan Fungsi Jaringan Tumbuhan menunjukkan bahwa pada aspek konseptual, untuk kesesuaian kompetensi dengan Kompetensi Dasar dan kesesuaian kegiatan dengan tingkat kognitif siswa, persentasenya hanya $16,6 \%$. Pada aspek praktikal $66,7 \%$ dari LKPD yang dianalisis prosedurnya tidak tepat sehingga objek fenomena yang muncul tidak relevan dengan tujuan/judul LKPD. Pada aspek konstruksi pengetahuan 66,6\% dari LKPD yang dianalisis pertanyaannya dapat dijawab tanpa melakukan praktikum dan tidak ada pertanyaan mengenai interpretasi data, kemunculan suatu prinsip dan analisis sehingga penarikan kesimpulan tidak berdasarkan fakta dan tidak menggambarkan judul/tujuan. Berdasarkan perolehan skor komponen Diagram Vee LKPD Struktur dan Fungsi Jaringan Tumbuhan belum mencapai skor ideal (18). Komponen Diagram Vee yang tidak muncul sama sekali adalah klaim pengetahuan (skor 0). Hasil tersebut merupakan dasar untuk melakukan modifikasi dan rekonstruksi terhadap LKPD Struktur dan Fungsi Jaringan Tumbuhan. Saran, Sebaiknya sebelum melaksanakan praktikum guru perlu menganalisis dan mengujicoba serta merekonstruksi terlebih dahulu LKPD yang disediakan sekolah untuk mengetahui LKPD tersebut layak atau tidak digunakan sebagai pedoman praktikum agar kegiatan praktikum yang dilaksanakan bermakna dan sesuai dengan tujuan pembelajaran.

\section{DAFTAR PUSTAKA}

Agustina, E. (2016). Analisis Kesesuaian Materi Kuliah dengan Materi Praktikum Biologi Bidang Tumbuhan pada Program Studi Pendidikan Biologiuin Ar-Raniry. Jurnal Biotik, 4(2), 156-162.

Azmi, N., Prastowo, P., \& Maslena. (2018). Analisis Kesesuaian Lembar Kerja Peserta Didik (LKPD) Biologi Kelas X yang digunakan MAN Rantauprapat Kabupaten Labuhan Batu. Jurnal Pelita Pendidikan, 6(2), 65-70.

Bago, A. S. (2018). Pengembangan Penuntun Praktikum Biologi disertai Gambar pada Materi Jaringan Tumbuhan Berbasis Guided Discovery untuk Siswa SMA Se Kecamatan Telukdalam. Jurnal Education and Development, 5(2), 85-90.

Dahar R W. (2011). Teori-teori Belajar. Jakarta: Erlangga.

Festile, R. M. (2017). The Influence of Practical Work in the Teaching and Learning of Acids, Bases and Neutrals in Natural Sciences. Cape: University of the Western Cape. 
Hakim, N. (2015). Penerapan Project-Based Learning Dipadu Group Investigetion Untuk Meningkatkan Motivasi, dan Hasil Belajar Mahasiswa Pendidikan Biologi Universitas Muhammadiyah Malang. Jurnal BIODIK, 1(1).

Hashim, S., Mohaffyza Mohamad, M., \& Nadrah Wan Muda, W. H. (2018). Knowledge Construction Models: A view of Various Models for an Impeccable Learning Environment. MATEC Web of Conferences, 1-7. http://doi.org/10.1051/matecconf/201815005013

Hindriana, A. F. (2016). the Development of Biology Practicum Learning Based on Vee Diagram for Reducing Student Cognitive Load. JETL (Journal Of Education, Teaching and Learning), 1(2), 61. http://doi.org/10.26737/jetl.v1i2.39

Hindriana, A. F. (2020). Pengembangan Lembar Kerja Praktikum Berbasis Diagram Vee Guna Memfasilitasi Kegiatan Laboratorium Secara Bermakna. Quagga: Jurnal Pendidikan Dan Biologi, 12(1), 62-68.

http://doi.org/10.25134/quagga.v12i1.2331

Holman, J. (2017). Good Practical Science. London: The Gatsby Charitable Foundation.

Laelasari, I., \& Supriatno, B. (2018). Analisis Komponen Penyusun Desain Kegiatan Laboratorium Bioteknologi. Jurnal Bioedukatika, 6(2), 84-90. http://doi.org/10.26555/bioedukatika.v6i2.10592

Maemunah, S., \& Pramesti, I. (2019). Pengembangan Modul Jaringan Tumbuhan Berbasis Pendekatan Contextual Teaching and Learning ( CTL), 2(2), 129-136.

Millar, R \& Abrahams, I. (2009). Practical work - Research Database, The University of York. School Science Review, 91(334), 59-64. http://doi.org/10.1007/978-3319-07857-1_2

Millar, R. (2004). The Role of Practical Work in The Teaching and Learning of Science. Washington DC: National Academy of Sciences.

Novak, \& Gowin. (1984). Learning How to Learn. New York: Cambridge University Press.

Putri, N. E., Yolida, B., \& Sikumbang, D. (2019). Hubungan Pelaksanaan Praktikum dan Keterampilan Proses Sains Terhadap Hasil Belajar Peserta Didik, 7(4), 92103.

Rima, R., Munandar, A., \& Anggraeni, S. (2020). Pengembangan Kegiatan Praktikum Pemodelan Efek Rumah Kaca untuk Siswa SMA pada Materi Perubahan Lingkungan. Assimilation: Indonesian Journal of Biology Education, 3(1), 34-38. http://doi.org/10.17509/aijbe.v3i1.23308

Sadikin, A., \& Hakim, N. (2019). Buku Ajar Berbantuan Model Pembelajaran Everyone is A Teacher Here: Upaya Meningkatkan Keterampilan Dasar Mengajar Calon Guru Biologi. Assimilation: Indonesian Journal of Biology Education, 2(2), 47-51. https://doi.org/10.17509/aijbe.v2i2.19249

Safahi, L., Pusporini, A., Susilo, S., \& Akbar, B. (2020). Analisis Keterampilan Proses

Sains Calon Guru Biologi Terhadap HOTS. BIODIK, 6(1), 35-45.

Supriatno, B. (2009). Uji Langkah Kerja Laboratorium Sekolah. Proseding Seminar

Nasional Biologi: Inovasi dan Pendidikan Biologi dalam Pengembangan Sumber Daya Manusia (pp. 255-261).

Sadikin, A. (2018). Penerapan jurnal belajar untuk meningkatkan motivasi belajar 
mahasiswa pada mata kuliah Dasar-Dasar dan Proses Pembelajaran Biologi. Bioeducation Journal, 2(1), 70-75.

Supriatno, B. (2018). Praktikum untuk Membangun Kompetensi. Proceeding Biology Education Conference (Vol. 15, pp. 1-18).

Sadikin, A. (2015). Hubungan EQ (Emotional Quotient) dengan hasil belajar mahasiswa biologi semester Ganjil Tahun Ajaran 2014/2015. BIODIK, 1(1).

The Society for Biology. (2010). The Importance of Practical Biology: from School to Higher Education. Retrieved from www.societyofbiology.org.

Wahidah, N. S., Supriatno, B., \& Kusumastuti, M. N. (2018). Assimilation: Indonesian Journal of Biology Education, 1(2), 70-76.

https://doi.org/10.17509/aijbe.v1i2.13050

Wibowo, Y. G., \& Sadikin, A. (2019). Biology in the 21st-Century: Transformation in biology science and education in supporting the sustainable development goals. JPBI (Jurnal Pendidikan Biologi Indonesia), 5(2), 285-296. https://doi.org/10.22219/jpbi.v5i2.7956

Woolfolk, A. (2008). Educational Psychology.(10th ed.). New Jersey: Allyn and Bacon.

Zulfaidhah, Z., Palenewen, E., \& Hardoko, A. (2018). Needs Analysis in the Problem Based Learning (PBL) Model Tools and Problems Regarding 7th Grade Students' Science Learning Outcome at SMPN 2 Bongan. BIODIK, 4(1), 48-59. https://doi.org/10.22437/bio.v4i1.5508 